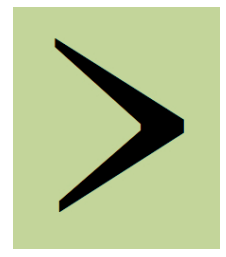

\author{
Papers in Historical Phonology \\ http://journals.ed.ac.uk/pihph \\ ISSN 2399-6714 \\ Volume 3, 96-122 (2018) \\ DOI : $10.2218 /$ pihph.3.2018.2827
}

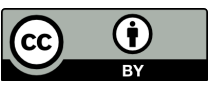

Licensed under a

Creative

Commons 4.0

International

License

\title{
The Anatolian Dissimilation Rule Revisited
}

\author{
PAUL S. COHEN \\ Unaffiliated \\ ADAM HYLLESTED \\ University of Copenhagen
}

\begin{abstract}
The Anatolian Dissimilation Rule $(A D R)$ was first introduced in an oral presentation by us in 2006 and first published by us in 2012, though it had, in several fundamental aspects, been prefigured in articles by, e.g., Gillian Hart and Birgit Olsen. The ADR expresses the following sound change(s): ProtoIndo-European ${ }^{*} h_{3}>\{$ Hittite $\check{s}$; Luvian $t / d$; Lycian, Milyan $t$; Lydian $s\} / \# \#$ $X$ Labiovelar $Y$, where $X$ and $Y$ are arbitrary (possibly null) phone strings and $X$ does not contain \#. There are five PIE roots/words with attested reflexes in Anatolian that are subject to the $A D R$, and all of them exhibit the appropriate outcomes: ${ }^{*} h_{3} O k^{w_{-}}$'eye', ${ }^{*} h_{3} \bar{e} h_{2} u r$ 'urine', ${ }^{*} h_{3} n g w h_{-}$'fingernail, toenail', ${ }^{*} h_{3}$ óng ${ }^{w} n$ 'fat, butter, oil, salve', ${ }^{*} h_{3}(o) r h_{2}$ uent- 'innards, intestine(s)'. The $A D R$ covers all relevant items exceptionlessly; nevertheless, it has not been widely accepted. Potential reasons-both Anatolian-specific and more generally phonological—will be discussed and rebutted below, in the light of our previous arguments/suggestions and some newly added and upgraded ones.
\end{abstract}

\section{Introduction}

The Anatolian Dissimilation Rule (ADR) was first introduced in an oral presentation (Cohen \& Hyllested 2006) and first published-with much less associated detail-in Cohen \& Hyllested (2012), though it had, in several fundamental aspects, been prefigured in, e.g., Hart (2004) and Olsen $(1992,2006) .{ }^{1}$ As given in Cohen \& Hyllested $(2012,63)$, the $A D R$

1 In fact, as appropriately cited by Olsen (1992), the idea of ${ }^{*} h_{3}>$ Hittite $\check{s}$ in environments like that of the $A D R$ has been in the literature since, at least, Schindler (1969). Schindler, moreover, notes (p. 159) that already in 1957 Kuryłowicz had presented the pattern of Hittite showing ša for PIE * $o$ (as Kuryłowicz reconstructed it at the time); see Kuryłowicz $(1958,226)$. 
expresses the following sound change(s): Proto-Indo-European ${ }^{*} h_{3}{ }^{2}>$

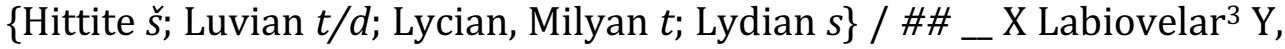
where $\mathrm{X}$ and $\mathrm{Y}$ are arbitrary (possibly null) phone strings and $\mathrm{X}$ does not contain \#. We propose that the change occurred in two stages: In Stage 1 , PIE ${ }^{*} h_{3}$ became a Proto-Anatolian palatal affricate (see discussion in item c of section 4 below); in Stage 2, that affricate merged, languagedependently, with an extant stop or fricative.

There are five 4 PIE roots/words with attested reflexes in Anatolian that are subject to the $A D R$, and all of them exhibit the appropriate outcomes:

- $\quad$ PIE ${ }^{*} h_{3} o{ }^{w_{-}}$'eye' > Hitt. šăkui-, šākuwa- 'id.'; Luv. tāwa/ī 'id.'; Lyc. tewe'id.'; Mil. tewe- 'to face'; Lyd. saw- 'to see'5

- PIE * $h_{3} \bar{e} h_{2} u r_{0}$ 'urine' > Hitt. šêhur / šêhun- 'id.'; Luv. dūr / dūn- 'id.'

- $\quad$ PIE * $h_{3} n g^{w h} h_{-}$'fingernail, toenail' > Hitt. šankuwai-, šankui- 'id.'; Luv. tammūga- 'nails' or 'nail-clippings'

- PIE * $h_{3}$ óngwn 'fat, butter, oil, salve' > Hitt. šāgan 'oil, fat'; PIE * $h_{3} n g$ wến 'id. (collective)' > Luv. tāìn / tāin / dā̄̄n 6 'oil, fat'

- PIE *h $h_{3}(o) r h_{2}$ uent- 'innards; intestine(s)' > Hitt. šarḩuwant- 'belly, innards, womb; fetus' (cognate with Gk. óví 'intestine, gut; sausage')

\footnotetext{
${ }^{2}$ In keeping, for the most part, with the generally-accepted view, we take ${ }^{*} h_{3}$ to have been a voiced, labialized, faucal (i.e., non-glottal post-velar) fricative. But it should be noted that some scholars assume ${ }^{*} h_{3}$ (and ${ }^{*} h_{2}$ ) were velar, and at first blush this appears reasonable, since it would provide fricatives matching, respectively, the PIE stops ${ }^{*} g^{w}$ and ${ }^{*} k$ in voicing, location, and labialization. However, the presumption that ${ }^{*} h_{3}$ and ${ }^{*} h_{2}$ were velar leads to a major problem: The velar stops did not color PIE ${ }^{*} e$, but ${ }^{*} h_{3}$ and ${ }^{*} h_{2}$ did (to ${ }^{*} o$ and ${ }^{*} a$, respectively); and, cross-linguistically, such coloration is typical of faucals, but not of velars. We give detailed discussion and references in Cohen \& Hyllested (2012, 54-57), and write "Articulatorily, velar and uvular fricatives (and approximants) often have a wider range of position than the phonologically corresponding stops"; we also (pp. 56f.) give examples from three living languages: Modern German, the Dutch of the Netherlands vs. that of Belgium, and Cimbrian.

${ }^{3}$ The PIE class of phonological labiovelars is comprised of ${ }^{*} k^{w},{ }^{*} g^{w},{ }^{*} g^{w h},{ }^{*} u$, and ${ }^{*} h_{3}$ - though there are no generally-accepted roots that have the sequence ${ }^{*} h_{3} \ldots * h_{3}(\ldots)$, and, indeed, such a sequence would violate a PIE root-structure constraint that prohibits roots of the form $C_{i} V C_{i} \ldots$ (see, e.g., Weiss 2009, 44 and Cooper 2009, 56).

${ }^{4}$ In addition, some authorities reconstruct the PIE 'bird'-word as * $h_{3} e$ unis, and derive the Hittite hapax šuwais, glossed as 'bird', from it. The $A D R$ would yield the Hittite form straightforwardly; however, Kloekhorst $(2008,795)$ concludes, in agreement with strong arguments given by Yoram Cohen (2010, esp. 35f.), that šuwais actually means 'rejection'. This position appears to be well-founded, and, if correct, šuwais has become irrelevant to our discussion.

${ }^{5}$ Abbreviations used in this paper: Anat $=$ Anatolian; Arm = Armenian; Av $=$ Avestan; Germ = German; Gk = Greek; Hitt = Hittite; IE = Indo-European; IIr = Indo-Iranian; Ir = Iranian; Lat = Latin; Lit = Literary; Lith = Lithuanian; Luv = Luvian; Lyc = Lycian; Lyd = Lydian; Mil = Milyan; Mod = Modern $; \mathrm{OHG}=$ Old High German; OIc = Old Icelandic; ON = Old Norse; $\mathrm{P}=$ Proto; $\mathrm{Pal}=$ Palaic; Pers = Persian; SerbCS $=$ Serbian Church Slavonic; $\mathrm{Sl}=$ Slavic; Skt $=$ Sanskrit; Toch $=$ Tocharian; Ved = Vedic.

${ }^{6}$ Although voiced and voiceless stops in Luvian are distinguished intervocalically, "Voiceless stops have been generalized in word-initial position..." (Melchert 1994, 229). We keep the original spellings of quoted forms, but otherwise use $<\mathrm{t}>$ or $<\mathrm{t} / \mathrm{d}>$ for the relevant Luvian phone.
} 
The ADR covers all the relevant items exceptionlessly. Moreover, it has two other salutary effects:

(i) It eliminates the need for the ad hoc invoking of $s$-mobile in the Anatolian forms.

(ii) It explains the otherwise anomalous correspondence of Hitt. $\check{s}$ and, e.g., Luv. $t / d$.

\section{Anatolian-specific issues and our proposed solutions}

Despite its benefits, the $A D R$ has not been widely accepted. We address the relevant general-phonological issues in section 4 below, while focusing here on Anatolian-specific considerations, in the light of our previous arguments/suggestions and some newly upgraded ones.

It turns out that many (perhaps, most) specialists who reject the $A D R$ focus on the details of potential issues in the etymological generation of Hitt. šagan 'oil, fat' and Luv. tāìn / tāin 'id.'. We believe that those details are taken care of in our newly revised formulations (the novel portions of which are indicated by italicization of the relevant parenthesized material in the derivations). For šagan, we offer the following:

(i) PIE * $h_{3}$ óngwñ (an uncontroversial form)

(ii) > PAnat. *dzóng ${ }^{w} n$ (via Stage 1 of the $A D R$ )

(iii) > PAnat. *dzóngñ (via a rule proposed by Manaster Ramer 2011; ${ }^{7}$ potentially controversial; discussion immediately below)

(iv) > PAnat. *đ̧ógn (via another rule proposed by Manaster Ramer 2011; potentially controversial; discussion immediately below)

(v) > PHitt. *šógn (via Stage 2 of the Hitt. version of the ADR)

(vi) > PHitt. *šágn (uncontroversial; see Melchert 1994, 105)

(vii) > Hitt. šāgan (uncontroversial; see Melchert 1994, 181)

Step 3, delabializing the labiovelar stop, instantiates Manaster Ramer's $(2011,1)$ proposal that PIE labiovelars undergo unrounding in Anatolian when preceded by ${ }^{*} n,{ }^{*} m,{ }^{*} l$, or ${ }^{*} s$, unless followed by a rounded vowel. He gives at least seven etymologies-including one for šāgan that is, however, substantially different from ours-based on the rule in Step 3. (Cohen \& Hyllested 2006 had come up with a much narrower version of this rule, one that we no longer advocate.)

${ }^{7}$ Manaster Ramer has given the first author written permission to distribute his work where appropriate; we will email a copy of his 2011 ms. to those requesting it. 
Step 4 instantiates another proposal by Manaster Ramer (2011, 3), namely that nasals are-perhaps irregularly-deleted before a sequence of consonant + nasal. Sporadic deletion of nasals before consonants (i.e., without consideration of what immediately follows the consonant) in Hittite has been generally accepted since the publication of Justesen \& Stephens (1981) or even earlier; so it would not be surprising if this process were reinforced by another nasal in the environment. Olsen $(2006,239 f$.) gives an incipient version of the ideas detailed by Manaster Ramer, writing,

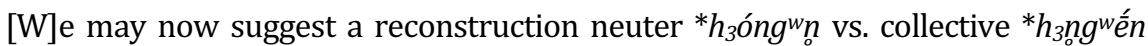
with a potentially dissimilatory deletion of *n (cf. Hitt. kattan $<* \hat{k} m t$ - 'beneath') and delabialization of the labiovelar....

(It should be noted that Manaster Ramer, as with his unrounding rule, supports his proposed nasal-loss rule with further Hittite etymologies.)

For tāīn / tāin, we offer:

(i) PIE *h3ngwến (because it is a collective form, perhaps mildly controversial - but typically [as by Olsen] accepted; Oettinger 2003,340 , i.a., adduces a collective here, although his underlying form does not have an initial laryngeal.)

(ii) > PAnat. *đ̧̧ngwến (via Stage 1 of the $A D R$ )

(iii) > PAnat. *ḑangwến (uncontroversial; see Melchert 1994, 260)

(iv) > PAnat. *ḑagwến (via the rule proposed by Manaster Ramer 2011: 3, as in Step 4 of our etymology of Hitt. šāgan above; potentially controversial)

(v) > PLuv. *dagwén (via Stage 2 of the Luv. version of the $A D R$ )

(vi) > PLuv. *dayến (via a straightforward modification of rules given by Melchert 1994, 254, 280; discussion immediately below)

(vii) > PLuv. *tayến (uncontroversial; see fn. 6 above)

(viii) > PLuv. *tayín (uncontroversial; see Melchert 1994, 254, 263)

(ix) > PLuv. *taín (uncontroversial; see Melchert 1994, 254, 280)

(x) > PLuv. *táin (presumed accent shift because of unusual accent position and/or vowel sequence ${ }^{8}$ )

(xi) > Luv. tāìn / tāin (uncontroversial; see Melchert 1994, 264, 281)

\footnotetext{
${ }^{8}$ As Melchert $(1994,247)$ writes, "[W] can infer the place of the Luvian accent only indirectly from its secondary effects." We have inferred the accent shift because of the $\bar{a}$ in Step 11's attested forms, which is the Luvian reflex of * $a$ in accented open syllables (see Melchert 1994, 264).
} 
Step 6, requires only a small, phonologically unsurprising adjustment in Melchert's rules for the development of the Proto-Anatolian voiced dorsals in Proto-Luvian. ${ }^{9}$ He writes (p. 254): “(1) The PA[nat.] voiced labiovelar */gw / does appear to be weakened to /w/ in all positions." and "(2) Both */ $\hat{\mathrm{g}} /$ and */g/ become /y/ before front vowel, disappearing before /i/." But none of his examples for $* / \mathrm{gw}^{\mathrm{w}}$ are before a front vowel. We propose that the two (ordered) rules are to be restated as follows:

(i) $* / \mathrm{gw} /$ becomes $/ \mathrm{w} /$ before non-front vowels

(ii) $* / \mathrm{gw} /, * / \hat{\mathrm{g}} /$, and $* / \mathrm{g} /$ become $/ \mathrm{y} /$ before front vowels, disappearing before /i/

\title{
3 Other researchers' opposing accounts/solutions/proposals that do not presume $A D R$-like change to underlying ${ }^{*} h_{3}$, and our rebuttals
}

\subsection{H. Craig Melchert's (long-held) position ${ }^{10}$}

Melchert (1994, 274f.) writes,

\begin{abstract}
In two words [PAnat.] initial */s/ appears irregularly as a Luvian dental stop: *sogwo/ih- 'eye, face' > tāwa/ī- ..., pl. tāwa (= Hitt. pl. šākuwa) ...; *sếhwr/sếhun'urine' > dūr/dūn- (= Hitt. šęhur/šęhun-) .... The semantic and morphological match between Hittite and Luvian in both [emphasis Melchert's] words makes unlikely any attempt to derive the forms from different PIE sources ....
\end{abstract}

He goes on (p. 275) to refer to this as a "sporadic change".

Also, Melchert ([1993] 2001, 204) has an entry for tammüga-, glossed as 'nail (clippings)'. The entry ends with "Since reference is to nail clippings, may be deriv. of tamma-,11 not actual word for 'toe/finger-nail."'

In an email on June 9,2005, Melchert was kind enough to give us a frank, in-depth critique of a draft of Cohen \& Hyllested (2006). In it, he writes:

\footnotetext{
9 Notably, Melchert $(1994,253 f$.) states as preface to the relevant rules, "The development of the voiced dorsals in Luvian is complex and not yet entirely certain.... The evidence remains limited and contradictory, and readers should view the presentation below as provisional."

10 Melchert has very recently informed us (p.c.) that he has modified his position on some of these items and issues. However, both because of the fact that many influential researchers base their positions on what is in Melchert's published work and the proximity to our deadline (less than two weeks), we have kept this portion of this subsection essentially unchanged. At the time for submission of the present paper, Melchert had not yet gotten back to us to delineate his latest position.

${ }^{11}$ At the entry for tamma/i-, which is glossed as "'removed; captured' (?)", we find, after some diffident argumentation concerning the gloss, "... thus 'that which is removed' (?). Cf. tammūga-."
} 
... I cannot remotely accept the idea of Hittite initial s- = Luvian t/d- reflecting a dissimilation of initial ${ }^{*} \mathrm{~h} 3$ - before a labiovelar or ${ }^{*} w$ later in the word.... I find the proposed change quite incredible purely in phonetic terms.... The matter of *initial* Hittite $\mathrm{s}=$ Luvian $\mathrm{t} / \mathrm{d}$ is certainly a difficult problem to which I do not have a solution, but the dissimilation from *h3 is definitely not the answer.

Later in the same email, he writes:

Whatever you do with Hittite sankuwai-, you really should not repeat Hart's absurd attempt to derive tammuga- from the same source. She labels the phonological development 'complex'. It is quite unbelievable....

He then gives his objections to her "ad hoc changes" and her failure to account for the geminate - $\mathrm{mm}$ - in the item, and continues, "Since the word in context means 'nail *clippings*', it is likely that the word is derived from the root*(s)temh1- 'cut'." Later still, he writes: "The real problem for your idea is Hittite sagan- = Luvian ta(:)in- 'oil, fat'..." and after listing what he sees as insuperable problems with our first attempts at rule-governed derivationsproblems that we believe we have solved in the present paper-ends the section as follows:

In sum, the 'oil, fat' word simply cannot be derived from a preform with a labiovelar or with a nasal in the root. I stand by my claim that the cognate of sagan-=ta:in- is Latin sagi:na.

And he winds up the substantive portion of his critique by stating:

None of us who work on Anatolian have yet been able to make the 'smobile+laryngeal' solution work to our satisfaction, but something along these lines still seems the most promising in view of sankuwai-, and in principle it could be applied to several of the others. But the phonetics remain unexplained, and the entire status of s-mobile before laryngeal is, needless to say, sub iudice. ${ }^{12}$

\subsection{Our rebuttal of Melchert's (long-held) position}

a. Any appeal to a sporadic phonological change with no attempt at explanation is, to put it mildly, ipso facto suspect-all the more so when a single rule-governed explanation (viz., the $A D R$ ) is available that yields the correct outcomes for all extant examples.

b. Melchert's etymologies of the PAnat. 'eye'-word and 'urine'-word presume that these are reflexes of PIE forms with initial ${ }^{*}{ }^{*}{ }^{13}$ The PIE

\footnotetext{
12 I.e., 'not yet decided'.

13 Indeed, in accordance with the chapter entitled "Changes from PIE to Proto-Anatolian" in Melchert (1994, 60-91), this would be, for Melchert, the only possible path to an inherited PAnat. * $s$ (as given on p. 63), either inherent to the root or an $s$-mobile.
} 
root for 'eye' is uncontroversially reconstructed to have been ${ }^{*} h_{3} O k^{w_{-}}$ (i.e., just as we have cited it in the present paper). Melchert would either have to adduce $s$-mobile as the source of the initial ${ }^{*} s$ in the PAnat. reflex he propounds (sók $k^{w} O-$ 'seeing' [p. 61]) or support another PIE etymon,

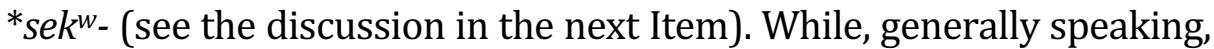
the introduction of $s$-mobile is not a cause for concern, it is, in the case at hand, problematical: Even though fundamentally nominal reflexes of the 'eye'-root are found in all eleven well-attested extra-Anatolian PIE families, in none of these does the root evince an initial PIE * $s$. In fact, of those eleven families, it is only in Albanian and Germanic that forms of interest beginning with ${ }^{*} s$ show up, and these reflexes are fundamentally verbal, not nominal. ${ }^{14}$

c. The relevant PIE root is *sek ${ }^{w_{-}}$'to follow'; in eight (Baltic, Celtic, Germanic, Greek, Indic, Iranian, Italic, and Slavic) of the nine families where it is attested, there are reflexes meaning 'to follow' or the like (see LIV [525f. s.v. * sek ${ }^{u_{-}}$'sich anschließen']). And, in keeping with most handbooks, we would argue, of course, that the meaning 'to see' found in Albanian shoh (derivable from ${ }^{*} s e s \hat{k}-e / o-<{ }^{*} s e k^{w}-s \hat{k}-e / o-$, as demonstrated in Hyllested 2013) and in various Germanic languages is a straightforward semantic development from 'to follow (with the eyes)'.15

d. In his published writings, Melchert does not give a source for the PAnat. 'urine'-word. However, in an email to the first author (27 February, 2018), he states:
The correct account in my view is given by Le Feuvre ${ }^{16}$..., which also takes into account Luvian se(h)w- 'bitter, sharp'. Just what the phonetics are of Luvian du:r 'urine' with generalized *sh $2 \mathrm{u}$ - remain less than obvious, but it's not the only such case where Luvian has a dental stop from *s+laryngeal.

There are several issues to touch on with respect to Le Feuvre's and Melchert's positions on the 'urine'-word:

\footnotetext{
${ }^{14}$ Albanian sy 'eye' is generally regarded as coming from ${ }^{*} h_{3} k^{w_{-}-i H}$, the dual of ${ }^{*} h_{3} O k^{w_{-}}$: The $s$ of $s y$ cannot have come from PIE initial ${ }^{*} s$, which yields, depending upon stress, $/ \check{s} /($ written $<\mathrm{sh}>$ ) or $/ \hat{\mathrm{g}} /($ written $<\mathrm{gj}>$ ). In contrast, a reflex beginning with $s$ is unexceptionable, since, regularly in Albanian, initial ${ }^{*} h_{3}$ is lost (thus Hyllested 2012, 75f.) and ${ }^{*} k^{w}>s$ before front vowels.

15 E.g., within LIV's entry for *sek ${ }^{u_{-}}$'sich anschließen' (i.e., 'to follow'), attached to Gothic saihuan 'sehen' (i.e., 'to see'), we find fn. 7 (p. 526), which states: "Wird oft unter Annahme semant. Wandels 'sehen, im Auge haben' $\leftarrow$ '(mit dem Blick) folgen' hierher gestellt." (i.e., 'Often placed here under the assumption of the semantic change 'to see, to have one's eye on' $\leftarrow$ 'to follow (with one's glance)'.').

16 Referring to Le Feuvre (2007, 112f.).
} 
(i) Le Feuvre $(2007,127 \mathrm{f}$.), in the English-language summary of her paper, reconstructs

... an old acrostatic *uer- / *uen- neuter stem, from the root ${ }^{*} \operatorname{seh}_{2^{-}}$ « to soil », preserved in Hittite sēhur « impure corporeal [sic] secretion, urine » $<{ }^{*} s e ̂ h_{2} u r$, with Eichner's law ...

as the PIE etymon for Gk. عí $\rho \omega \varepsilon \varepsilon \varsigma$ 'damp, moldy', OHG sūr, OIc. surr, Lith. súras, and Sl. syrŭ (and, obviously, for Hitt. šêhur / šêhun-). We are agnostic as concerns Le Feuvre's etymology tying together the Greek items on one side and the established Germanic and Balto-Slavic word-family on the other, but we maintain that the PIE form is not germane for the derivation of Hitt. šehur / še ȩhun-, Luv. dūr / dūn-. For both semantic and phonological reasons, we have found it far more convincing to follow the general outlines of the analysis given by Olsen (2006, 240f.), who gives derivations of the Anatolian forms, as well as Gk. oṽoov 'urine', Lat. ūring 'urine', and ON úr 'drizzling rain' from PIE * $h_{3} \bar{e} h_{2} u r$ ' 'urine'. Moreover, it should be kept in mind that Anatolian is generally believed to have separated from PIE before any other attested language group did. In that regard, Olsen's solution has the added benefit of starting with the noun 'urine' as the primary PIE meaning of the etymon, thereby allowing us to place the Anatolian forms, which have the same meaning, temporally closer to their immediate forerunner. ${ }^{17}$ Verb forms, e.g. Hitt. šêhuriie/a-zi 'to urinate', are transparently derived from the noun (see, e.g., Kloekhorst 2008, 742 s.v. šēhur / šêhun-). Le Feuvre's etymology, on the other hand, makes a verb root primary and thus the derived noun secondary.

(ii) Le Feuvre does not even mention Luv. dūr / dūn (which, as we have seen, Melchert concedes must be related to Hitt. šêhur / šehun-, though he cannot offer a relevant rule-governed process).

(iii) In the body of her paper, Le Feuvre (p. 112) slyly glosses Hitt. šêhur as " "sécrétion corporelle impure », et plus particulièrement " urine "".18 But it should be kept firmly in mind that there is no evidence that Hitt. šêhur / šêhun- (or, for that matter, Luv. dūr / $d \bar{u} n$ ) ever refers to anything but urine.

\footnotetext{
17 This is perfectly in keeping with the fact that Hitt. šẹhur / šeehun- and Luv. dūr / dūn are members of the archaic $r / n$ heteroclitic noun class.

18 I.e., "impure bodily secretion', and more particularly 'urine".
} 
e. In direct contradiction of Melchert's statement cited near the end of section 3.1 above, we believe that in section 2 we in fact gave explicit, viable Hittite and Luvian derivations of the 'oil'-word "... from a preform with a labiovelar [and] with a nasal in the root." In addition, we find completely unconvincing Melchert's proposal that Lat. sagina is cognate with the Anatolian 'oil'-word. First of all, sagina means 'a cramming, stuffing, fattening, and the like', and so the putative semantics are farfetched at best. And sagina has no secure cognates. We note, furthermore, that Oettinger $(2011,4)$ also rejects Melchert's proposal.

f. Because Luv. tammüga- 'nails' or 'nail-clippings' is a hapax, it is uncertain which of its two glosses is the correct one, and therefore whether it is indeed cognate with Hitt. šankuwai-, šankui- 'fingernail, toenail'. However, i.a., both Schindler $(1969,159)$ and Hart $(2004$, 344f.), citing Kuryłowicz (1958, 226), advocate the cognacy of the Hittite and Luvian forms, and-as quoted in section 3.3 and discussed in section 3.4 below-Oettinger $(2011,3)$ does so as well. We think the items are probably cognates, but even if they are not, we still have the Hittite forms cognate with items in Baltic, Celtic, Germanic, Greek, Indic, Iranian, Italic, Slavic, and Tocharian meaning 'nail, claw', none of which exhibits $s$-mobile, and all of which are derivable from PIE ${ }^{*} h_{3} n g^{w h_{-}}$or a full-grade variant thereof. In any event, we offer for consideration here a possible derivation of tammūga- from ${ }^{*} h_{3} n g^{w h_{-}}$.

(i) PIE * $h_{3 n}$ g $^{w h}$ - (uncontroversial ${ }^{19}$ )

(ii) > PAnat. * $d_{3} n g^{h} u$ - (via Stage 1 of the $A D R$; with PIE labiovelar stops phonologically interpreted in the new system as sequences of stop + the phoneme $* u$ )

(iii) > PAnat. * dzang ${ }^{h}$ - (uncontroversial; see Melchert 1994, 260)

(iv) > PAnat. ${ }^{*}$ dzangu- (loss of distinctive aspiration in stops; uncontroversial; see Melchert 1994, 53f., 60)

(v) > PLuv. *tangu- (via Stage 2 of the $A D R$ )

\footnotetext{
19 The two possible reconstructions ${ }^{*} h_{3} n g^{w h}$ - (with an aspirated labiovelar in the root) and ${ }^{*} h_{3} n g^{h}-\underline{n}$ - (with a plain aspirated velar followed by a labial suffix) are both widespread and can be characterized as equally uncontroversial. The latter, however, is based mainly on the fact that the word is a $u$-stem in several languages; but there is no explicit evidence for a consonantal - $u$ - in any of the languages that can demonstrate the difference between ${ }^{*} g^{w h}$ and ${ }^{*} g^{h} u$ : Neither Indo-Iranian, nor Baltic, nor Slavic displays the regular outcome $-v$-. We adhere, herein, to the reconstruction with an aspirated labiovelar, in agreement with, i.a., Adams (2013, 502), Baldi $(2002,244)$, Derksen (2015, 327), Kroonen $(2013,381)$, Meier-Brügger $(2010,254)$, and Stiles $(2017,896)$.
} 
(vi) > PLuv. *tamgu- (assimilation of nasal to labiality of a following phonetic labiovelar, hereby posited; ${ }^{20}$ presumably controversial)

(vii) > PLuv. *tammgu- (gemination of /m/ before a consonant; uncontroversial; see Melchert 1994, 266)

(viii) > PLuv. *tammug- (phonetic adjustment for pronounceability, hereby posited;21 presumably controversial)

(ix) > Luv. tammūg- $\left(* / \mathrm{u} />/ \overline{\mathrm{u}} / / C_{1} V\right.$; uncontroversial; see Melchert 1994, 241)

In addition we note that nothing precludes the possibility that the PIE 'nail'-word had - $m$ - which was preserved in Luwic and Tocharian, but assimilated in Hittite and Core IE independently. And, in fact, an assimilatory development of the opposite type (i.e., change of a velar to a labial in a labiovelar context) is attested: In the Mongolic language Eastern Yugur, naykwa 'heaven' is a loanword from Amdo Tibetan; cf. Lit. Tibetan nam-mkha' 'id.' (see Nugteren 2011, 237).

\subsection{Norbert Oettinger's position}

Oettinger (2003, 340), correcting Kimball's (1999, 92f.) analysis of Hitt. ša-kán-da, writes:

Es ist ... ein eigenes Wort /sagan-, sagn-/ „Öl, Fett" anzusetzen, das m.E. im luwischen tāìn-gleicher Bedeutung seine Entsprechung hat. Letzteres stammt

\footnotetext{
20 There is ample cross-linguistic precedent for this rule. E.g.: 1) English sandwich, which is typically pronounced with the /d/ elided (i.e., with medial /nw/), appears side by side with jocular/dialectal samwich (with medial $/ \mathrm{mw} /$ ) as well as jocular/dialectal sangwich (with medial $/ \mathrm{n}(\mathrm{g}) \mathrm{w} /$ ) - thereby indicating that the $/ \mathrm{w} /$ is truly labiovelar, since it can induce an assimilated labial or velar nasal. 2) Toch. A auk < Pre-Toch. *amk ${ }^{*}$ $<{ }^{*} h_{2}$ eng ${ }^{w h}$ - 'snake' (reconstructions by Georges-Jean Pinault, p.c. to the second author), unless the Pre-Tocharian form is a reflex of PIE ${ }^{*} h_{2} e m g^{w h}$ - with original $m$. 3) The 'nail'word itself undergoes a distant assimilation in Toch. B mekwa, A maku, 'nail' < ProtoToch. *mekwā (Adams 2013, 502) and possibly also in Arm. magil 'id.', although the latter may have been contaminated by matn 'finger' (Olsen 1985, 13, Clackson 2017, 111). In a word of very similar structure, the same development takes place, this time shared with Iranian: PIE *neg ${ }^{w}$-nó- 'naked' becomes Arm. merk (and lerk) for expected therk, and Iranian forms such as Av. mayna and Mod.Pers. barahna- point to PIr. *magna- or *bagna- 'naked' for expected †nagna- (and indeed from IIr. *nagna-).

${ }^{21}$ Although, as we pointed out in section 2 above, Melchert $(1994,254)$ writes that, in Luvian, PAnat. “...*/gw/ does appear to be weakened to /w/ in all positions ...", he has no examples after nasals (and we know of no others). We can thus adduce-just as Hart $(2004,345)$ did-Lat. ninguit 'it snows', as contrasted with nix, nivis 'snow', to support a different treatment of ${ }^{*} g^{w}$ (i.e., $>/ g /$ ) in this position.
} 
aus einem Kollektivum *sog-ến gegenüber heth. /sagan-/ < Sg.N-A. *sóg-ñ ; mehr dazu sowie zum Anlaut des luwischen Wortes an anderer Stelle. ${ }^{22}$

Oettinger (2011) is the handout (written in English) for his Copenhagen lecture (delivered in German), which was attended by both of the present authors; in it, he presented, i.a., his position on derivations and possible cognates of the Anatolian 'urine-word', 'eye'-word, 'oil'-word, and 'nail'-word, which we will quote and summarize here:

- 'urine'-word (pp. 1f.): “Hitt. sēhur, gen. sēhunas n. 'urine'; Luw. dūr. Luw. si(h)una-, sìhuaia/i- 'bitter, sour', si(h)ūāl 'dagger'."

He continues:

Semanti[cs]: A) 'pricking, piercing'[,] Germ. 'stechend'. B) 'tasting bitterly [sic]', Germ. 'stechend (scharf) schmeckend'.... Hitt. sēhur 'urine' < *séh ${ }_{2}$-ur. derived adjective: *sh ${ }_{2} u r$-ó- > *suh ${ }_{2}$ ró- > *süró- 'sour'... Derived from *seh ${ }^{*}$ - is

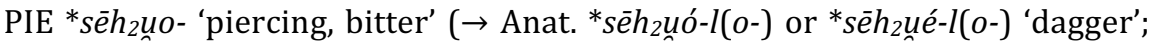

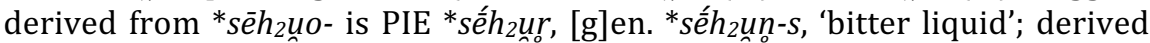
from * $s e ́ h_{2} u r$ is Germanic and Balto[-]Slavic *suh $h_{2} r-o ́$ - 'containing bitter liquid' (Engl. sour, Slav. syrb 'wet, raw; cheese', Lith. súras 'salty').

- 'eye'-word (p. 3): "PIE * (s)h $h_{3} o k w$ - 'eye' Hitt. sākuuna, Luw. dāuna."

- ' 'oil'-word (p. 3): "PIE *shég- $(m) n$ n > sakan 'oil', collective *sh ${ }_{3} g e ̂ ́ n$ (gen.

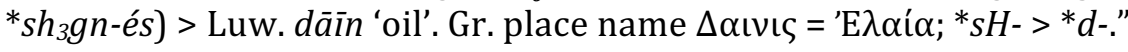

- 'nail'-word (p. 3): "PIE collective * $(s) h_{3 n} g_{0}{ }^{h}$-ú-óli 'fingernails' (cf. Lat. unguis 'nail' > Hitt. sankuua äi, Luw. dammuga (coll.), probably with metathesis of $u$

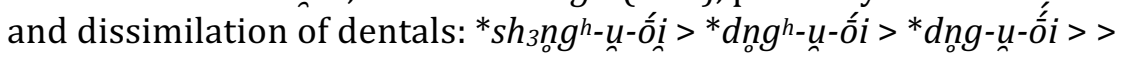
*dñ́nugāi $>$ > *dñ́mugāi > dammuga."

On p. 4, Oettinger propounds the following developments:

a) Early-PIE [*] $s h_{2} V->$ Late-PIE ${ }^{*} d h_{2} V->d V$ -

b) PA[nat]. ${ }^{*} h_{2} V-,{ }^{*} s h_{3} V->$ Luw. ${ }^{*} d H V->d V$ -

As support, he had adduced (p. 3)

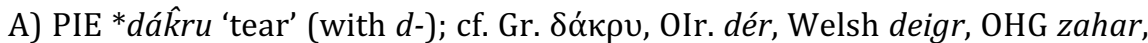
Arm. artōsr (*drak̂kru $<* d a \hat{k} r u)$. B) PIE variant *ákru without $d-;$ cf. Ved. áśru 'tear', Lith. ãšara, Toch. B obl. pl. akrūna. C) Hitt. ishahru $\ll{ }^{*} s_{2} a ́ k \hat{k} r u<$ ${ }^{*} \mathrm{sh}_{2} \hat{e} \hat{k} r u$.

\footnotetext{
${ }^{22}$ I.e., 'It is to be attached to a separate word, /sagan-, sagn-/ 'oil, fat' that in my opinion has its counterpart in Luvian tāin with the same meaning. The latter is derived from a collective *sog-én, as against Hitt. /sagan-/ < nom.-acc. sing. *sóg-ñ; more about that as well as the initial sound of the Luvian word in another place.' (We note, however, that we have had no success in locating the "other place" to which Oettinger made reference; but see the discussion later in this subsection.)
} 
After which he declares:

PIE *dákru is the regular development of PIE *sh ${ }_{2} a \hat{k} r u$ with $s$-mobile. The PIE variant *ákru stems from ${ }^{*} h_{2} a ́ k \hat{k} u$ without $s$-mobile. Cf. Luw. tahhara- (/dahra-/ may well mean 'tear'. ${ }^{23}$ In Luwian u-stems are recessive.)

He then asks the rhetorical question, "How to explain the strange phonetic development ${ }^{*} s_{2^{-}}>d-?$ ?", which he answers with the suggestion, "Maybe the dental fricative $s$ became a dental occlusive $d$ by dissimilation to the following fricative $h_{2} \ldots .$.

\subsection{Our rebuttal of Oettinger's position}

To his credit, Oettinger makes an attempt at a unified solution-i.e., one that avoids sporadicity-for all four items (including the 'nail'-word) that exhibit the Hittite $\breve{s} \sim$ Luvian $t / d$ correspondence in initial position. But we consider our derivations/explanations to be superior for several reasons:

a. As with the derivations Melchert uses as support for his long-held position, Oettinger's derivations all require an initial * $s$. This, in turn, requires his resorting to the use of $s$-mobile for the 'eye'-word, and 'nail'-word. But there is no cogent extra-Anatolian evidence whatsoever for an $s$-mobile in either of them.

b. For the 'urine'-word, Oettinger, like Le Feuvre, adduces an underlying PIE verb form * seh $_{2}$-. Le Feuvre assigns it a meaning of 'to soil', whereas Oettinger writes $(2011,1)$ 'PIE * seh $_{2}$ - meant not 'be dirty' but 'prick, pierce'." 24 In any case, the argument we gave against Le Feuvre's etymology in section 3.1 above (see point d(i)) works just as well against Oettinger's.

c. For the 'oil'-word, Oettinger has chosen not to embrace a straightforward Anatolian connection with the widespread PIE root ${ }^{*} h_{3}{ }^{\prime}{ }^{*}{ }^{w}{ }_{0}$. This is presumably because, at the time, he found problems with potential derivations from ${ }^{*} h_{3}$ óng $^{w}{ }_{0}$. We believe we have taken steps to ameliorate/eliminate such problems with our derivations in

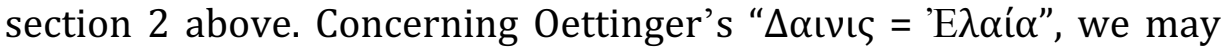
well be seeing here an earlier Luvian form that was later replaced by a Greek translation: Thus, specifically, Melchert ([1993] 2001, 202 s.v.

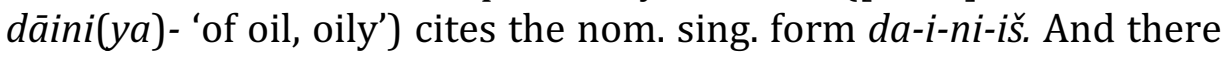

23 Melchert ([1993] 2001, 201) gives only '?' as a gloss for tahhara-.

24 We note without further comment that neither LIV nor Kümmel (2018) list any relevant root with initial ${ }^{*} s e h_{2}$ or ${ }^{*} s h_{2}$. 
is strong philological support as well: In a discussion entitled "Aeneas' realm in the Troad", Woudhuizen $(2006,93)$ writes:

[The] region south of Mount Ida with which Aeneas seems to be associated is also reported to be inhabited by Leleges and/or Kilikes.... Both the ethnonyms Leleges and Kilikes are indicative of Luwian speaking population groups.... Evidently we are dealing here with settlers from Luwian speaking areas to the south and southeast, who moved across the language border[,] as determined by Dainis (< Luwian tāini- "oily") being the indigenous name of later Greek Elaia ${ }^{25}$ (= harbor of Pergamon)[,] ... into a presumably Thraco-Phrygian milieu....

d. We take care of all relevant items with a single, unified rule involving ${ }^{*} h_{3}$, whereas Oettinger needs ${ }^{*} h_{2}$ (for the 'urine'-word). This, in fact, leads him into further complications. To start with, he now has to bring in a controversial etymology dependent on $s$-mobile for PIE *dákru 'tear', so as to have an example to motivate his purported (separate!) sequences of changes of Early-PIE ${ }^{*} h_{2} V$ - >> Late-PIE $d V$ and of PAnat. ${ }^{*} s h_{2} V$-, ${ }^{*} s h_{3} V$ - $>>$ Luv. $d V$-. But, in fact, the normal outcome of Early-PIE ${ }^{*}{ }_{2} h_{2} V$ - is that it remains in (Late-)PIE. Thus, e.g., Hitt. išhamāi- 'song, melody' and its cognate Skt. sấman- 'song, hymn, chant' go back to a PIE root beginning with ${ }^{*} s_{2} V .{ }^{26}$

e. We leave it to the reader to decide whether our dissimilation rule (i.e., the $A D R$ ) is more plausible than Oettinger's suggested dissimilatory change ${ }^{*} s>d / \ldots h$, a change he himself characterized as a "strange phonetic development". In any case, surely our overall solution has fewer rules and assumptions than his, and is therefore, via Ockham's razor, to be preferred.

\subsection{Alwin Kloekhorst's position}

Kloekhorst (2008) has six entries directly relevant to the $A D R$. On pp. 698f. s.v. šăkan / šăkn 'oil, fat', he writes:

PIE * $\operatorname{só}^{\prime \prime}(h)-n, s^{\prime \prime}(h)-n$-ós.... Although no good IE cognate is known, the inflection of this word looks so archaic that an IE origin is likely.... Oettinger $(2003,340)$ adduces CLuw. tāin- 'oil', which he assumes to reflect collective ${ }^{*} \operatorname{sog}$-én. ${ }^{27}$ Although semantically this connection is convincing, the formal side is difficult, especially with regard to the initial $t$ - in CLuwian. Nevertheless, there

\footnotetext{
25 This is the Greek word for 'olive (tree)'.

${ }^{26}$ Kloekhorst (2008: 394 s.v. išhamāi-i / išhamāi- 'to sing') gives detailed argumentation supporting a Pre-Hitt. root ${ }^{*} \mathrm{sh}_{2} \mathrm{em}$ - for the Hitt. noun. Mallory \& Adams (520: s.v. sing) have a subentry for ${ }^{*} s h_{2}$ ómen- 'song' (transparently a normal o-grade with the nominalizing suffix ${ }^{*}$-men).

27 I.e., in the quotation we gave at the beginning of section 3.3 above.
} 
are some other words in which CLuw. $t$ - seems to correspond to Hitt. $\check{s}$-: CLuw. tāua /i- Hitt. šăkuua- 'eye' and CLuw. dūr / dūn- Hitt. šēhur / šēhun- 'urine'. It is remarkable that in all these cases we are dealing with a word in which PAnat. ${ }^{*} g$ disappeared in Luwian.

On pp. 704, 706 s.v. šākuuna- 'eye':

(p. 704) PAnat. *sógwo-. IE cognates: PGerm. *sexwan 'to see'. PIE *sókw-o-.... (p. 706) The interpretation of CLuw. tāua/i-, HLuw. [i.e., Hieroglyphic Luvian] tawa/i- and Lyc. tewe- 'eye' is difficult.... In my view, the formal and semantic similarity between Luw. tāua/i- and Hitt. šăkuua- is too big not to attempt connecting them etymologically. The latter part of the word is no problem .... The initial part is more problematic, however: Luw./Lyc. $t$ - does not regularly correspond to Hitt. $\breve{s}$. Yet there are a few more words in which we do find this correspondence: CLuw. tāin- 'oil' could possibly belong with šâkan / šakn- 'oil' and CLuw. dūr / dūn- 'urine' could possibly belong with Hitt. šêhur / še êhun'urine'. When compared to Luw. tāua $/ i-\sim$ Hitt. šâkuua , we notice that in all these cases we are dealing with a word in which PAnat. */g/, */g/ or */gw/ is

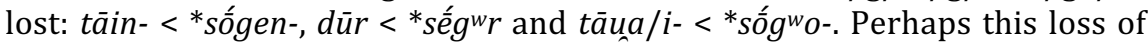
$* / \mathrm{g} /$ was a decisive factor in the development of PAnat. ${ }^{*} s$ - to pre-Luw. ${ }^{*} t$ -

On p. 723,725 s.v. šankuūāi- 'nail; a unit of linear measure':

(p. 723) PIE ${ }^{*} s-h_{3} n g h-u-o i-? . .$. (p. 725) [T] his word is generally connected with

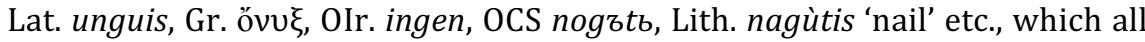
point to PIE ${ }^{*} h_{3} n e g^{h}-u-,{ }^{*} h_{3} n g^{h-u-\ldots . . ~ T h i s ~ c o n n e c t i o n ~ d o e s ~ n o t ~ a c c o u n t ~ f o r ~ t h e ~}$ initial $\check{s}$-, however.... Nevertheless, if we assume an $s$-mobile (which is admittedly quite $a d h o c$ ), then we can reconstruct ${ }^{*} s-h_{3} n g^{h}$ - $u$-oi- which would regularly yield Hitt. šankuuai-.28

On p. 733 s.v. (UZU) šarhuuant- 'belly; innards; foetus, unborn child':

IE cognates: Arm. argand 'womb'? PIE *srh ${ }_{2}$ uent- ??... The only credible etymology I know of ... connect[s] this word with Arm argand 'womb'. If the Armenian sound laws permit it, we could reconstruct * srh $_{2}$ uent- ${ }^{29}$

\section{On p. 742 s.v. šêhur / šêhun- 'urine':}

PIE * séik ${ }^{w} r$, séikwn- ??... [A reconstruction of] šēhurur as *šé-hূur, a derivative in -ur of the root ${ }^{*} \mathrm{seh}_{2^{-}}$'veruneinigen, beschmutzen' ... has been widely followed.... Nevertheless, a root ${ }^{*} \operatorname{seh}_{2-}$ 'verunreinigen, beschmutzen'30 does

\footnotetext{
${ }^{28}$ Kloekhorst (2008) makes no mention of Luv. tammüga.

29 Martirosyan $(2010,131$ s.v. argand 'womb') discusses the etymology of argand and the word's potential cognacy with Hitt. šarhuuant- (and, in passing, with Gk. óvó $\alpha$ ), after which he writes, "I conclude that the etymology of argand remains uncertain." Based on this and on discussions the second author had with Birgit Olsen on 23 May, 2011, we concur, and so we have adduced only Gk. ópvo as cognate to šarhuuant-. See also Olsen (2006, 239 with fn. 12).

30 I.e., 'to pollute, to soil'.
} 
not occur in Hittite. The verb šāh ${ }^{-i}$... in fact means 'to clog, to stuff, to stop, to block, to fill in, to plug up' and probably reflects PIE * seh $_{2^{-}}$'to stuff up' (from which * seh $_{2-}$ 'to satiate').... I see no reason ... to assume that šêhur must reflect *šé-hur... It is quite common that words like 'urine' are borrowed because of tabooistic reasons.... I ... assume borrowing from another Anatolian language.

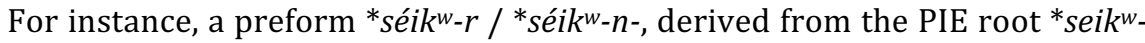
(OHG seihhen 'to urinate', SerbCS sbcati 'to piss', Skt siñcáti 'to pour out', etc.), would yield šẹhur / šēhun- in Palaic by sound laws: PIE *séikw-r / *séikw-n'urine' > PAnat. *ség ${ }^{w} r /{ }^{*}$ ség ${ }^{w} n->$ Pal. šēhuur / šēhuun-.... Although it is hard to prove, I would certainly regard borrowing from Palaic (or another Anatolian language where PAnat. ${ }^{*} g^{w}$ yielded $-h u$ - as a possibility).

And on p. 899 s.v. dūr / dūn 'urine':

\begin{abstract}
PIE * séikw-r, séikwn-?... Because of the use of gloss-wedges, it is likely that the word is Luwian.... CLuw. dūr [has been] connected with Hitt. šêhur / šêhun'urine' ... which is semantically appealing.... Nevertheless, details are unclear. As I have argued s.v. šêhur / šẹhun-, I believe that this word was borrowed into Hittite from another Anatolian language (Palaic?) in which PIE *séikw-r / *séik ${ }^{w}$-n- regularly yielded šêhur / šêhun-. Although the details regarding the initial consonant are not fully clear, I believe that in Luwian a [preform] ${ }^{*} C e ́ i k^{w} r$ would through PAnat. ${ }^{*} C \bar{e} g^{w} r$ and pre-Luwian ${ }^{*} C \bar{e}{ }^{w}{ }^{w} r$ yield CLuw. Cür. Note that in the other words where Luwian $t$ - seems to correspond to Hitt. $\check{s}^{-}$, we are also dealing with the loss of a Proto-Anat. ${ }^{*} g$ in Luwian (CLuw. tāua $/ i$ $\sim$ Hitt. šākuua- 'eye' < *sókwo-, CLuw. tāin- Hitt. šākan / šakn- 'oil' < *sóg(h)_ $(e) n$-). Perhaps this loss of PAnat. ${ }^{*}-g$ - caused initial ${ }^{*} s$ - to yield Luw. $t$-, although the phonetic details remain obscure.
\end{abstract}

\title{
3.6 Our rebuttal of Kloekhorst's position
}

Kloekhorst's stance about a potential source for the correspondence of initial-position Hitt. $s \sim$ Luv. $t / d$, as quoted in section 3.5 above, varies from tentativeness ("The initial part is ... problematic.... Perhaps ... loss of * $/ \mathrm{g} /$ was a decisive factor in the development of PAnat. *s- to pre-Luw. *t-.") to apparent wonderment ("It is remarkable that in all these cases we are dealing with a word in which PAnat. * $g$ disappeared in Luwian."). And it is easy to see why. For one thing, such a rule (i.e., something like "* $s$ becomes $t$ if and only if * $g$, following later in the word, has been lost"), even if it is feasible to write it in one's choice of framework, is remarkably counterintuitive and, we would argue, probably not a "possible sound change" in the sense laid out in Honeybone (2016). But there are still other ways in which we find Kloekhorst's arguments, to put it mildly, unconvincing.

In order to manufacture a ${ }^{*} g$ (to be later deleted in Luvian and not yielding a $k$ in Hittite) for the 'urine'-word, Kloekhorst has to resort to positing an unattested form borrowed (from Palaic or from another language he cannot name) into both Hittite and Luvian. So he adduces

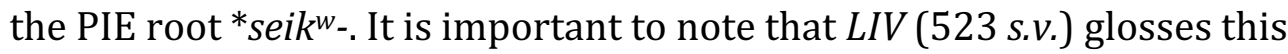


root as 'ausgiessen' (i.e., 'to pour out'). The root has reflexes in Germanic, Greek, Indic, Iranian, Italic, Slavic, and Tocharian. In Indic and Iranian, the reflexes in fact mean 'to pour out' or 'to become empty'; in Greek, 'to sieve'; in Tocharian, 'to become flooded'; in Italic, 'to pour out' or 'to scoop/dip' (also, as a deverbal noun, 'ladle'); in Germanic, 'to sieve' or 'to piss' (Old High German evinces both meanings); and in Slavic, 'to piss'. Surely, these meanings taken as a group indicate that 'to piss' is not the

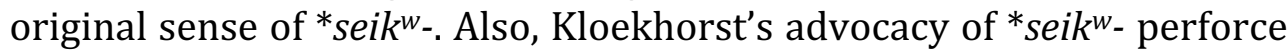
makes the verb primary and thus the noun a secondary formation. This is of course the opposite of the Hittite situation, where Kloekhorst (2008, 742 s.v. šēhur / šêhun- 'urine') himself writes that šēhuriie /a-zi, šêhurae-zi 'to urinate' are "Derivatives".

As with Melchert and Oettinger, many of the problems apparent in Kloekhorst's etymologies for the items under consideration stem from his unquestioning (and, in fact, ill-founded) assumption that the relevant PIE etyma must begin with * $s$ : So, for the 'oil'-word he gives, with no otherwise attested reflexes, "PIE * sóg' $(h)-n$, sğ $(h)-n$-ós"; for the 'eye-word' the only extra-Anatolian cognate he proposes is "PGerm. *sexwan 'to see" (a verb!); for the 'nail'-word he gives a PIE form with an $s$-mobile "which is admittedly quite ad hoc"; and, as discussed in the preceding paragraph, for the 'urine-word' he turns to "PIE *séik ${ }^{w} r$, séik ${ }^{w} n$ - ??" (note the doubled question mark).

Finally, it is noteworthy that Kloekhorst does not mention Luv. tammüga-: If he were to accept its cognacy with Hitt. šankuwai-, šankui-, the $g$ in the Luvian word would, of course, force him to renounce his suggestion that "loss of * $/ \mathrm{g} / \mathrm{was}$ a decisive factor in the development of PAnat. ${ }^{*}$ - to pre-Luw. ${ }^{*} t$-."

\subsection{Andrew Miles Byrd's position}

As the title of his 2012 presentation implies, Byrd's focus is not primarily on the topic of the present article; nevertheless, he has a novel suggestion for handling the Hitt. $s \sim$ Luv. $t$ relationship, which we will discuss. First of all, it should be noted that he is attempting to deal with both initial and medial position. The latter is a complex topic, discussing which would take us far afield (and far beyond our space limitations); we will therefore leave it for another time. With respect to direct relevance for the $s \sim t$ relationship, Byrd references nothing later than 2006 (he includes Čop 1965, Hart 2004, Olsen 2006, and Cohen \& Hyllested 2006), and thus some of the data he cites are outdated/irrelevant-most notably, the 'bird'-word (see fn. 4 above). Byrd (2012, 5, 1st slide) begins an analysis of the 'eye'-word, 'urine'-word, and 'oil'-word that he 
attributes to Čop (1965), though Čop never mentions the 'oil'-word there. Byrd gives:

Hitt. $\operatorname{sag}^{w} a-\quad$ Luv. tāwa/i-, Lyc. *tewe

$<$ PAnat. * sóg $^{w}$ o- 'eye, face'; cf. English see

Proto-Luvian ${ }^{*} s a \gamma^{w} a-$

Hitt. sēxur Luv. tūr

$<$ PAnat. *sēhwr 'urine'; cf. PIE *sehz-'defile'

Proto-Luvian *siGur

Hitt. sagan- Luv. tāyin-

$<$ PAnat. *sagēe/an ${ }^{31}$ 'oil'; cf. Latin sagīna 'stuffing, feeding'

Proto-Luvian *sayin

He annotates the Luvian and Lycian forms with "lenition".

On p. 6, both slides are entitled "Past Analyses (Hart et al.)". The first slide reads as follows:

Hart (cf. also Olsen 2006; Cohen \& Hyllested 2006):

1. PIE ${ }^{*} h_{3} e ́ k^{w} O->$ Hitt. sagw ${ }^{w} a$, Luv. tāwa/i-

cf. Lat. oculus, Gk. óps, Eng. eye, etc.

2. PIE ${ }^{*} h_{3} O i h_{2} w r_{\circ}>$ Hitt. sēxur, Luv. tūr

cf. Lat. ūrīna, Gk. oũron

3. [not relevant for our present discussion]

The second slide, continuing the first, reads:

4. PIE ${ }^{*} h_{3}$ ong ${ }^{w} O_{-}->$Hitt. $\operatorname{sank}^{w} a-\sim$ Luv. tammuga-

taboo deformation?

5. PIE * $h_{3}$ wois > Hitt. $s(u)$ wais 'bird'

Lat. avis 'bird'? Gk. aietós 'eagle’?

Note that each form has:

1. ${ }^{*} \mathrm{~h}_{3}$

2. ${ }^{*} \mathrm{~W},{ }^{*} \mathrm{u}$

31 We do not know the source of Byrd's Proto-Anatolian reconstruction here. It may be his own; on the other hand, it is reminiscent of the one given by Oettinger $(2003,340)$, though Byrd does not list Oettinger on his References slide. 
Byrd's summary (intentionally or not) gives the reader the impression that, in the works cited, Hart, Olsen, and we are in general agreement about how to explain and codify the relevant ${ }^{*} \mathrm{~s} \sim{ }^{*}$ t material. This is far from the true situation, however. In fact there are quite a few differences among the three positions and the material handled. Focusing on the most significant ones:

Hart and Olsen list the vowel $u$ as a potential trigger for the Anatolian changes under consideration. We, explicitly, do not, and our formulation of the $A D R$ makes it clear why: $[\mathrm{u}]$ is not a labiovelar, and it thus cannot trigger labiovelar dissimilation; moreover, the $A D R$ works perfectly well without any reference to a putative role of [u].

Olsen lists labial stops as potential triggers for the changes. Again, we do not, for the same reasons as for [u].

Hart and we include Luv. tammüga- in the material we cover; Olsen makes no mention of tammüga-.

Olsen and we include the 'oil'-word; Hart does not.

On the first slide on p. 7, Byrd summarizes Hart's proposed derivation of the Anatolian items, and writes:

Though brilliantly simple, there are two main problems with Hart's hypothesis: 1 . In every case Hittite $s$ - may be original.... Alternate etymologies: ${ }^{*} s k^{w} O-,{ }^{*} s e \bar{e} \hbar_{2} w r, \ldots$ etc.... Who's to say it isn't $s$-mobile?

Continuing on the second slide on p. 7:

2. Must make difficult assumptions about the phonetics of the laryngeals! ... ${ }^{*} h_{3}=\left[\mathrm{\gamma}^{\mathrm{w}}\right]$ - does not account for vowel coloring! ... typical reconstruction of

${ }^{*} h_{3}=[\mathrm{G}]$ or $[\mathrm{G} w] \ldots$. It's not even certain that ${ }^{*} \mathrm{~h}_{3}$ was rounded!

On the first slide on p. 8, entitled "Take the Hittite at Face Value?", we find:

But what if each form began with a Proto-Anatolian ${ }^{*} s ?$... 1. Proto-Anat. *sógwo- 'eye, face'; cf. English see ... 2. Proto-Anat. *siGur 'urine' ... Proto-Anat. *sagan-/sagin- 'oil' ....

Then, on the second slide on p. 8, entitled "Today's Analysis":

1. Luv. tāwa/i-, Lyc. *tewe ... < Proto-Luvian *sa ${ }^{w} a-$ 'eye, face' ... 2. Luv. tūr / tūn- < Proto-Luvian *si̧ur 'urine' ... 3. Luv. tāyin- ... < Proto-Luvian *sayin-....

The slide concludes with his "process" of "Continuancy Dissimilation": "PAnat. * $s$ becomes $t$ in the vicinity of a dorsal fricative": "*s $>t / \ldots \ldots \gamma, \gamma^{w}, \subseteq\left[\right.$ or] $/ \hbar^{w} \ldots \ldots$. The portion of the rule relevant to our present concerns is ${ }^{*} s>t / \ldots \gamma, \gamma^{w}, \subseteq$. 
And on the first slide on p. 11, entitled “Any Problems?”, Byrd writes:

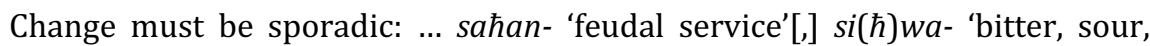

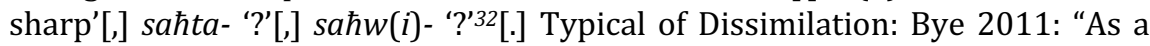
diachronic change, dissimilation is most often sporadic, applying to random lexical items[.]" ... Unanswered: Why dissimilation with a dorsal fricative only?

\subsection{Our rebuttal of Byrd's position}

There is much we disagree with Byrd about, but let us begin with a point on which he and we are in agreement: Having ${ }^{*} h_{3}=\left[\gamma^{\mathrm{w}}\right]$ does not account for vowel coloring. Vowel coloration of the sort found in PIE (i.e., backing-whether or not accompanied by rounding) is characteristically associated with faucals, as we discussed in detail in Cohen \& Hyllested (2012) ${ }^{33}$ (see fn. 2 above). Byrd is technically correct that we cannot be "certain that $* h_{3}$ was rounded", but, since the evidence strongly suggests that it was, this position is widely-held. Thus, e.g., Melchert $(1994,47)$ notes, "'Coloring' effects in PIE ... seem to require an element of rounding in $* / h_{3} / \ldots$..; Weiss $(2009,50)$ states, “One possible phonetic interpretation of the laryngeals is as follows: ... ${ }^{*} h_{3}=\left[\mathrm{Cw}^{\mathrm{w}}\right]$ (voiced, labialized, pharyngeal fricative)"; and Ringe $(2017,10)$ writes, "* $\mathrm{h}_{3}$ seems to have been voiced and apparently exhibited lip-rounding, to judge from the fact that it rounded adjacent short *e...". ${ }^{34}$

It is patently clear that Byrd's position requires that the relevant PAnat. forms begin with ${ }^{*} s$. Like Melchert, Oettinger, and Kloekhorst, this in turn forces him to postulate some very unappealing etyma: the 'eye'word with unparalleled $s$-mobile on the noun; the 'nail'-word with otherwise unattested and, in Kloekhorst's words, "quite ad hoc" s-mobile; the 'oil'-word and 'urine'-word putatively cognate with extra-Anatolian items that do not have the primary meanings, respectively, of 'oil, etc.' and (the basic noun) 'urine'. Our solution eliminates all these problems.

Byrd admits that his "process" of "Continuancy Dissimilation" must be a sporadic change, and then cleverly tries to put a positive spin on that admission by citing Bye's position on diachronic dissimilation. Of course, the operative words in the quotation from Bye are "most often". We note in passing that Bye gives no supporting statistics, and indeed focuses on synchronic dissimilation in his article. Most importantly, Byrd wonders

\footnotetext{
32 The forms and glosses he gives here are from Melchert ([1993] 2001).

33 We note that the final version of Cohen \& Hyllested (2012) was accepted for publication in 2011-i.e., before Byrd's SECOL presentation.

34 Of course, in keeping with the discussion in Cohen \& Hyllested $(2012,56)$, the PAnat. reflex of PIE $* h_{3}$, at a stage when coloring was no longer taking place, could have been phonetically labiovelar rather than (labio)faucal.
} 
why there is "dissimilation with a dorsal fricative only". ${ }^{35}$ We believe the answer is simple: What is triggering the dissimilation is not a dorsal fricative but rather two labiovelars in proximity.

We find Byrd's explanation remarkably unconvincing, but we will leave it to the reader to decide whether, in the light of the preceding paragraphs, it is explanatorily superior to the $A D R$.

\section{General-linguistic issues and our propounded solutions}

a. Is the change of a voiced, labialized faucal fricative into a voiceless apical or palatal obstruent a "possible sound change" (see, i.a., Honeybone 2016)? As is hardly debatable, any sound change is possible, given enough intermediate stages; however, the invoking of such an analysis is grasping at straws in the absence of supporting evidence either of (most of) the intermediate stages or from closely related languages. On the other hand, Blust (2005) gives an abundance of well-supported examples of what might appear to be far-fetched sound changes that are nonetheless attested, e.g., (p. 241) intervocalic devoicing of labiodental fricatives, palatal affricates, and velar stops (but not labial or alveolar stops) in Kiput (northern Sarawak).

b. Are exceptionless sound changes involving dissimilation-at-adistance "possible"? Or, put more traditionally, is dissimilation-at-adistance always sporadic? With literally dozens of indisputable examples of dissimilation-at-a-distance across many language families, Bennett (2015) apparently answers the latter question with a resounding no, but it is important to note that his focus is almost entirely on synchronic dissimilation (within his theoretical framework, which views dissimilation as instantiating constraints on phonological structure). He writes (p. 1, at the beginning of the Introduction):

The core idea: dissimilation from surface correspondence [....] The central point of this book is that surface correspondence also gives rise to dissimilation, in a novel way: dissimilation is not the avoidance of similarity for its own sake, but rather a response to more stringent conditions attached to similarity.

Thus we must ask whether, in the general case, synchronic and diachronic dissimilation are comparable? Bennett himself is vague on this point. He states (p. 325), "Dissimilatory historical sound changes seem rather frequent, but such cases are usually sporadic"; and ( $p$.

\footnotetext{
35 The similarity of Byrd's proposal to the diffident suggestion made by Oettinger, which we critiqued in section $3.4 \mathrm{e}$ above, is striking.
} 
364): "The situation is somewhat different if we include cases of diachronic dissimilation ...." However, he goes no further there. Our own position is straightforward: Independent of one's explanation for the cause(s) of dissimilation, we find it obvious that diachronic dissimilation is nothing more than the residue of whatever the synchronic process was.

So, in the light of Bennett's findings, is the $A D R$ a possible sound change or not? Two relevant points can be gleaned from his book:

- (p. 321) In a table entitled "Some dissimilation types attested for adjacent segments, but not over distance", Bennett lists Imdlawn Berber and Moroccan Arabic as languages exemplifying labialization dissimilation. In Bennett's framework, dissimilation of adjacent phones is a process completely distinct from dissimilation-at-a-distance. But we are far from convinced that that position is correct.

- (p. 330) Bennett notes that dissimilation (i.e., dissimilation-at-adistance) of labialization is not attested. However, nothing in Bennett's book would bar its existence.

But, most importantly, there are quite a few examples of exceptionless diachronic dissimilation-at-a-distance, e.g.:

- Dissimilation of initial $*_{n}>*^{*}$ in Hittite when another nasal follows later in the word; Katz (2005)

- Dissimilation of initial $h j$, originally an aspirated $j$ (phonetically, an unvoiced [j]), now pronounced as an affricate $\left[\mathfrak{g}^{\mathrm{h}}\right]$, to $j[\mathrm{j}]$ in Faroese before a sequence of vowel + aspirated liquid; e.g., hjálmar ['th'olmzı] 'helmet' vs. hjálpa ['jolpa] 'to help'; ${ }^{36}$ see Vrieland (2014)

- Palatalization of (velar) $k$ to (postalveolar) $c$ in Cowlitz Salishan when (uvular) $q$ follows later in the word; see Kinkade (1973), as cited in Drachman $(1978,131)$

- Dahl's Law in Northeast Bantu languages, whereby the first unvoiced stop in a sequence of two is voiced and, in some languages, also fricativized. In Kikuyu the law only affects $k$, which then becomes [ $\mathrm{\gamma}]$, as illustrated in the alternative spelling of the language name itself, Gikuyu (Kikuyu gĩkũyũ [ye:ko:jo]); see Bennett $(2015,91)$

\footnotetext{
36 In this example, the "combining ring below" is used in its IPA sense of devoicing, rather than-as elsewhere in the present paper-its Indo-Europeanist sense of syllabicity.
} 
More examples from across language families, and involving still further places and manners of articulation are listed in, e.g., Drachman (1978, 130f.), Anttila $(1989,75)$, and Fallon $(2002,203)$.

Our position with respect to the ADR is simple: We believe it is correct; it thus constitutes yet another valid example of exceptionless diachronic dissimilation-at-a-distance.

c. What influence does a language's synchronic phonological system (i.e., locations of phones in phonological space, or articulatory/acoustic features) have on the outcome of a phonemic change? We know that sound changes may or may not yield structural modifications; many sound changes-including the $A D R-$ involve (positional) allophones. If an allophone (i.e., not all instantiations of a phoneme) changes significantly it can

(i) disappear altogether or merge with an allophone of another phoneme: not yielding a structural modification (though changing some lexical representations); or

(ii) occupy an otherwise unoccupied location in phonological space: yielding a structural modification.

The $A D R$ would be an example of the second possibility. Note that Proto-Anatolian, at the stage before the formation of its daughterlanguages, is commonly reconstructed (see Melchert [1994: 53ff.]) as having the following inventory of consonantal phonemes and major allophones: $\quad * / \mathrm{p}, \mathrm{t}, \hat{\mathrm{k}}, \mathrm{k}, \mathrm{k}^{\mathrm{w}}, \mathrm{b}, \mathrm{d}, \hat{\mathrm{g}}, \mathrm{g}, \mathrm{g}^{\mathrm{w}}, \mathrm{s}, \mathrm{H}, \mathrm{h}, \mathrm{m}, \mathrm{n}, \mathrm{r}, \mathrm{l}, \mathrm{w}, \mathrm{y} / ; \quad *[\mathrm{z}] \quad$ (an allophone of $* / \mathrm{s} /$ ), *[ts] (an allophone of */t/ before $*[\mathrm{y}]$ ). In Melchert's transcriptional representation / $\mathrm{H} /$ is a fortis, voiceless, postvelar fricative and is the reflex, generally, of PIE * $/ h_{2} /$ (p. 68); $/ \mathrm{h} /$ is a lenis, voiced, postvelar fricative and is the reflex, generally, of $\mathrm{PIE}^{*} / \mathrm{h}_{3}$ / (pp. 71f.). Of course, the $A D R$ must have operated earlier in Proto-Anatolian (i.e., before $* / \mathrm{h}_{3} />$ (unrounded) $* / \mathrm{h} /$, and, indeed, to allow for the most parsimonious explanation of the $A D R$, must have comprised two stages:

(i) The allophone of PIE $* / h_{3} /$ in the environment delineated in the $A D R$ was dissimilated into a phone not then extant (and not very similar to any other phone) in Proto-Anatolian. Given its daughter-language reflexes, we think it likely that the phone was (something like) [dz] (or [t]]).

(ii) The addition of such a featurally different phone to the consonantal system would have caused instability; and in a later stage, it was eliminated by being merged into another phoneme that was relatively nearby in articulatory space-a coronal stop or coronal fricative, depending on the daughter-language 
(group). ${ }^{37}$ We, like Hart $(2004,348 f),.{ }^{38}$ are immediately reminded of the almost identical development in Greek, whereby PGk. */t: / [ $<$ PIE * $\left.k^{(w)} y,{ }^{*} g^{h(w)} y,{ }^{*} t y,{ }^{*} d^{h} y\right]>-\tau \tau$ - in Attic, Boeotian, and some West Ionic dialects, but $-\sigma \sigma$ - elsewhere.

d. It has been argued in structural linguistics, at least since Jakobson (1941), that phonetically difficult/complicated phones (often the term "marked" has been used) have specific characteristics that make them less stable. Haspelmath (2016) gives good arguments that, at least for our present purposes, we need only refer to phonetic difficulty and frequency (and treat markedness as an epiphenomenon); e.g., he writes (p. 57) that, "articulatory complexity can cause rarity ... and frequency can cause articulatory simplicity ...". This precept is sufficient to explain how few examples of the $A D R$ there are, given the phonetic difficulty/complexity and (thus) relative infrequency of ${ }^{*} h_{3}$ in PIE.

\section{Conclusions}

We believe that we have shown herein that the $A D R$ is a possible sound change. Moreover, we maintain that only the $A D R$-in direct contrast to its putative competitors-gives a complete description and explanation of the Anatolian material that we have examined in the present paper, and that material's connection to Proto-Indo-European. That is to say, in the still-cogent words of Ferdinand de Saussure from at least 140 years ago, it yields "un système où tout se tient". ${ }^{39}$

\footnotetext{
37 Of the Anatolian languages for which we have relevant data: in Hittite, it merged with /s/ (generally reconstructed as [̌̌]]); in Luvian and the languages usually grouped with it as "Luwic" (Lycian, Milyan, et al.), it merged with /t/; in Lydian, it merged with /s/. The situation with Lydian, a language that is neither well-attested nor well-understood and whose intra-Anatolian affiliation is unclear, is interesting: It is tempting to think that, based on the evidence from the $A D R$, Lydian is more closely related to Hittite than it is to the Luwic languages. This datum, among many others, has been examined, independently, by Friis $(2016,16)$ (who, however, misattributes the origination of the idea of the importance of the labiovelar in the environment's causing the apparently anomalous correspondences). In any case, she opts for a tenuous connection to Luwic, writing (p. 21), "In conclusion, the findings of this paper seem to indicate that Lydian had a slightly longer period of joint innovation with the Luwic branch than with HittitePalaic, but that it must have split off fairly early."

${ }^{38}$ Hart writes: "The correspondences discussed above form a coherent pattern. This appears similar to that of the Ancient Greek dialects...."

39 I.e., 'a system in which everything holds together.' See Koerner (1996/1997) for a detailed historiography of this phrase of Saussure's.
} 


\section{Comments invited}

PiHPh relies on post-publication review of the papers that it publishes. If you have any comments on this piece, please add them to its comments site. You are encouraged to consult this site after reading the paper, as there may be comments from other readers there, and replies from the author. This paper's site is here:

https://doi.org/10.2218/pihph.3.2018.2827

\section{Acknowledgements}

We thank Benji Wald for several suggestions that have improved content, examples, and presentation.

\section{Author contact details}

Paul S. Cohen

3271 Nutly Circle

Yorktown Heights, NY 10598

USA

pausyl@aol.com

Adam Hyllested

University of Copenhagen

Department of Nordic Studies and Linguistics

Søndre Campus, Emil Holms Kanal 2

DK-2300 Copenhagen S

Denmark

$a h @ h u m . k u . d k$

\section{References}

Adams, Douglas Q. 2013. Etymological dictionary of Tocharian B: Revised and greatly enlarged. Amsterdam \& New York: Rodopi.

Anttila, Raimo. 1989. Historical and comparative linguistics (Current Issues in Linguistic Theory 6). Amsterdam \& Philadelphia: John Benjamins.

Baldi, Philip. 2002. The foundations of Latin. Berlin \& New York: Mouton de Gruyter.

Bennett, William G. 2015. The phonology of consonants: Harmony, dissimilation, and correspondence. Cambridge: Cambridge University Press. 
Blust, Robert. 2005. Must sound change be linguistically motivated? Diachronica 22(2). 219-269.

Bye, Patrik. 2004. Dissimilation. In Marc van Oostendorp, Colin J. Ewen, Elizabeth Hume \& Keren Rice (eds.), The Blackwell companion to phonology, vol. 3 (Phonological processes), 1408-1433. Oxford: WileyBlackwell.

Byrd, Andrew Miles. 2012. The use of linguistic typology \& universals in IndoEuropean linguistics, with a brief note on the Hittite $s \sim$ Luvian $t$ correspondence. Slides dated 26 April, 2012 for paper presented on 13 April, 2012 at SECOL [Southeastern Conference on Linguistics] 79, Lexington, KY.

Clackson, James. 2017. Contamination and blending in Armenian etymology. In Bjarne Simmelkjær Sandgaard Hansen, Adam Hyllested, Anders Richardt Jørgensen, Guus Kroonen, Jenny Helena Larsson, Benedicte Nielsen Whitehead, Thomas Olander \& Tobias Mosbæk Søborg (eds.), Usque ad radices: Indo-European studies in honour of Birgit Anette Olsen, 99-115. Copenhagen: Museum Tusculanum.

Cohen, Paul S. \& Adam Hyllested. 2006. Initial $h_{3}$ in Anatolian: Regularity in ostensible chaos. Paper presented at the 18th Annual UCLA IndoEuropean Conference, Los Angeles, 4 November, 2006.

Cohen, Paul S. \& Adam Hyllested. 2012. A new sound law of PIE: Initial ${ }^{* *} h_{3} u$ $>^{*} h_{2}$ u. In Benedicte Nielsen Whitehead, Thomas Olander, Birgit Anette Olsen \& Jens Elmegård Rasmussen (eds.), The sound of Indo-European: Phonetics, phonemics, and morphophonemics, 53-72. Copenhagen: Museum Tusculanum.

Cohen, Yoram. 2010. Rara avis: A study of the HU section of the Sa Vocabulary. In Heather D. Baker, Eleanor Robson \& Gábor Zólyomi (eds.), Your praise is sweet: A memorial volume for Jeremy Black from students, colleagues and friends, 29-40. London: British Institute for the Study of Iraq.

Cooper, Adam I. 2009. Similarity avoidance in the Proto-Indo-European roots. University of Pennsylvania Working Papers (= Proceedings of the 32nd Annual Penn Linguistics Colloquium) 15(1). 55-64.

Čop, Bojan. 1965. Sur une règle phonétique de la langue louvite. Linguistica 7(2). 99-123.

Derksen, Rick. 2015. Etymological dictionary of the Baltic inherited lexicon. Leiden: Brill.

Drachman, Gaberell. 1978. Child language and language change: A conjecture and some refutations. In Jacek Fisiak (ed.), Recent developments in historical phonology, 123-144. The Hague: Mouton.

Fallon, Paul D. 2002. The synchronic and diachronic phonology of ejectives. New York \& London: Routledge.

Friis, Louise Skydsbjerg. 2016. The position of Lydian within Anatolian. Copenhagen: University of Copenhagen Bachelor's thesis. 
Hart, Gillian R. 2004. Some problems in Anatolian phonology and etymology. In John H. W. Penney (ed.), Indo-European perspectives: Studies in honour of Anna Morpurgo Davies, 341-354. Oxford: Oxford University Press.

Haspelmath, Martin. 2016. Against markedness (and what to replace it with). Journal of Linguistics 42(1). 25-70.

Honeybone, Patrick. 2016. Are there impossible changes? $\theta>\mathrm{f}$ but $\mathrm{f} \ngtr \theta$. Papers in Historical Phonology 1.316-358.

Hyllested, Adam. 2012. Albanian hundë 'nose' and Faroese, SW Norwegian skon 'snout'. In Stephanie W. Jamison, H. Craig Melchert \& Brent Vine (eds.), Proceedings of the 23rd annual UCLA Indo-European conference, 73-81. Bremen: Hempen.

Hyllested, Adam. 2013. Unexpected lengthened grade in Albanian. Paper presented at "The lengthened grade in Indo-European" Arbeitstagung of the Indogermanische Gesellschaft, Leiden, 30 July, 2013.

Jakobson, Roman. 1941. Kindersprache, Aphasie und allgemeine Lautgesetze. Uppsala: Almqvist \& Wiksell.

Justeson, John S. \& Laurence D. Stephens. 1981. Nasal + obstruent clusters in Hittite. Journal of the American Oriental Society 101(3). 367-370.

Katz, Joshua T. 2005. On the regularity of nasal dissimilation in Anatolian. Paper presented at the 17th Annual UCLA Indo-European Conference, Los Angeles, 28 October, 2005.

Kimball, Sara E. 1999. Hittite historical phonology. Innsbruck: Institut für Sprachwissenschaft der Universität Innsbruck.

Kinkade, M. Dale. 1973. The alveopalatal shift in Cowlitz Salish. International Journal of American Linguistics 39. 224-231.

Kloekhorst, Alwin. 2008. Etymological dictionary of the Hittite inherited lexicon. Leiden \& Boston: Brill.

Koerner, E. F. Konrad. 1996/1997. Notes on the history of the concept of language as a system "où tout se tient". Linguistica Atlantica 18/19. 1-20.

Kroonen, Guus. 2013. Etymological dictionary of Proto-Germanic. Leiden: Brill.

Kümmel, Martin. 2018. Addenda und Corrigenda zu LIV². (Version of 22 March, accessed on that date). http://liv2add-2.docx.

Kuryłowicz, Jerzy. 1958. New discoveries in Indo-European studies: A. le hittite. In Eva Sivertsen (ed.), Proceedings of the Eighth International Congress of Linguists, 216-243. Oslo: Oslo University Press.

Le Feuvre, Claire. 2007. Grec $\gamma \tilde{\eta}$ củ $\rho \omega ́ \varepsilon \sigma \sigma \alpha$, russe syra zemlya, vieil islandais saurr, « la terre humide » : Phraséologie indo- européenne et étymologie. Bulletin de la Société de linguistique de Paris 102(1). 101-129.

LIV = Martin Kümmel \& Helmut Rix (eds.). 2001. Lexikon der indogermanischen Verben, 2nd edn. Wiesbaden: Dr. Ludwig Reichert Verlag.

Mallory, James P. \& Douglas Q. Adams (eds.). 1997. Encyclopedia of IndoEuropean culture. Chicago \& London: Fitzroy Dearborn. 
Manaster Ramer, Alexis. 2011. Verschollene Redefiguren und verkannte Lautgesetze, oder Einige gewagte Erwägungen über das Anatolische seitens eines Figuranten: English ver. 2. Unpublished (and unfinished) ms., mostly in English but with some crucial sections in German. Emailed to the second author on 29 April, 2011.

Martirosyan, Hrach K. 2010. Etymological dictionary of the Armenian inherited lexicon. Leiden \& Boston: Brill.

Meier-Brügger, Michael. 2010. Indogermanische Sprachwissenschaft, 9th revised and supplemented edn. With contributions by Matthias Fritz \& Manfred Mayrhofer. Berlin: De Gruyter Studienbuch.

Melchert, H. Craig. [1993] 2001. Cuneiform Luvian lexicon. Corrected but otherwise unrevised online version of a print original. Chapel Hill, NC: selfpublished. http://linguistics.ucla.edu/people/Melchert/LUVLEX.pdf.

Melchert, H. Craig. 1994. Anatolian historical phonology. Amsterdam \& Atlanta: Rodopi.

Nugteren, Hans. 2011. Mongolic phonology and the Qinghai-Gansu languages. Leiden: University of Leiden doctoral dissertation.

Oettinger, Norbert. 2003. Review of Kimball (1999). Indogermanische Forschungen 108. 339-341.

Oettinger, Norbert. 2011. Anlautendes ${ }^{*} \mathrm{~s} H$-im Anatolischen: Word initial ${ }^{*} \mathrm{~s} H$ in Anatolian. Handout for lecture given at the "Anatolian Spring in Copenhagen" seminar, Copenhagen, 28 April, 2011.

Olsen, Birgit Anette. 1985. On the development of Indo-European prothetic vowels in Classical Armenian. Revue des études arméniennes 19. 5-17.

Olsen, Birgit Anette. 1992. Notulae indogermanicae I. Copenhagen Working Papers in Linguistics 2. 13-18.

Olsen, Birgit Anette. 2006. Hittite š from $\mathrm{h}_{3}$ ?. In Gerd Carling (ed.), Giš.turg gul-zaat-ta-ra: Festschrift for Folke Josephson, 237-247. Gothenburg: Meijerbergs Archiv för Svensk Ordforskning.

Ringe, Don. 2017. From Proto-Indo-European to Proto-Germanic, 2nd edn. Oxford: Oxford University Press.

Schindler, Jochem. 1969. Die idg. Wörter für 'Vogel' und 'Ei'. Die Sprache 15. 144-167.

Stiles, Patrick V. 2017. The phonology of Germanic. In Jared S. Klein, Brian D. Joseph \& Matthias A. Fritz (eds.), Handbook of historical and comparative Indo-European linguistics (HSK, Handbücher zur Sprach- und Kommunikationswissenschaft 41), vol. 2, 888-912. Berlin: De Gruyter.

Vrieland, Seán D. 2014. The pronunciation of $h j$ - in Modern Faroese. Arkiv för Nordisk Filologi 129. 233-244.

Weiss, Michael. 2009. Outline of the historical and comparative grammar of Latin. Ann Arbor, MI \& New York: Beech Stave.

Woudhuizen, Frederik Christiaan. 2006. The ethnicity of the Sea Peoples. Rotterdam: Erasmus University dissertation. 